\title{
Integrasi Konsep Ta'dib Al-Attas dalam Pembinaan Karakter Peserta Didik pada Masa Pandemi
}

\author{
Nurul Anifah ${ }^{1} \&$ Yunus $^{2}$ \\ ${ }^{1}$ Sekolah Dasar Negeri 156 Wonosari, Indonesia \\ ${ }^{2}$ Universitas Pamulang, Indonesia \\ Email: ${ }^{1}$ Nurulanifah47@gmail.com, ${ }^{2}$ nurhang542@gmail.com
}

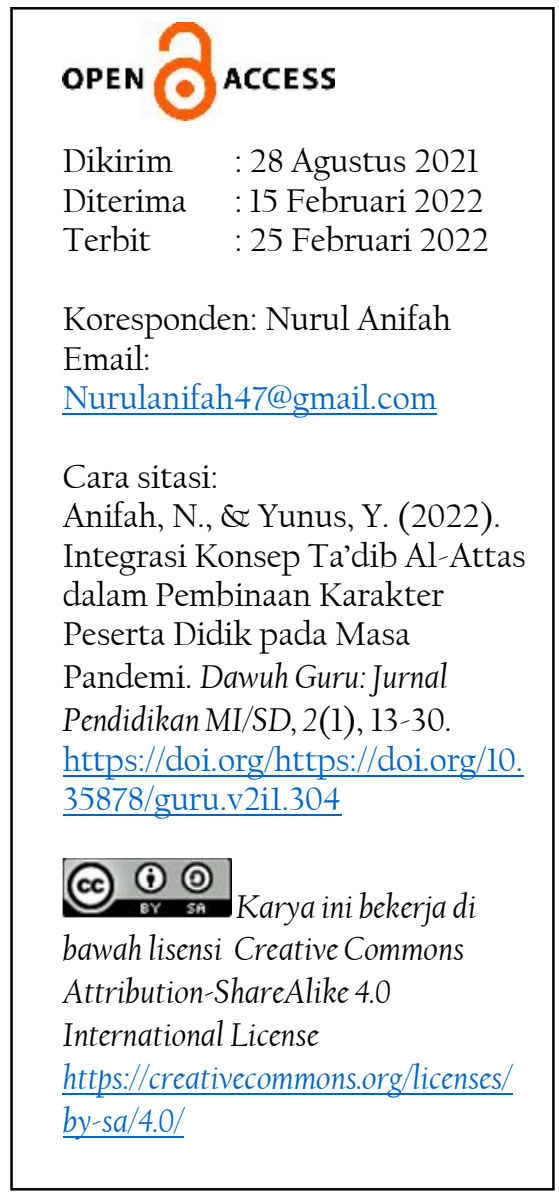

\begin{abstract}
In the pandemic, the world of education is able to adapt by continuing to carry out learning according to situations and conditions. This study describes the concept of Ta'dib Muhammad Naquib Al-Attas in Character Development of Students. This research is a qualitative research that uses a pedagogical approach. The results show that the concept of Ta'dib according to Muhammad Naquib Al-Attas, the concept of Ta'dib emphasizes the mastery of the right knowledge in a person in order to produce stable charity and good behavior based on faith. The concept of Ta'dib, first, as a moral competence (morals) that must be possessed by educators and students, second, the formation of personality so that a person's psychological characteristics related to the tendency to relate socially with others, especially those related to; friendliness, self-control, implementation can be said to be successful because of the adab education that is applied in the lives of students, but it must also be admitted that during the epidemic of Ta'dib education there are few obstacles, such as education level, environment, culture, socio-economic level and online learning.
\end{abstract}

Keywords: Ta'dib; Character Education; Covid-19

\begin{abstract}
Abstrak
Pada masa pandemi, dunia pendidikan harus mampu beradaptasi dengan tetap melakukan pembelajaran sesuai situasi dan kondisi. Penelitian ini mengambarkan Konsep Ta'dib Muhammad Naquib Al-Attas dalam Pengembangan Karakter Peserta Didik. Penelitian ini adalah penelitian kualitatif yang menggunakan pendekatan pedagogis. Hasil penelitian menunjukkan bahwa konsep Ta'dib menurut Muhammad Naquib Al-Attas, konsep Ta'dib titik tekan pada penguasaan ilmu yang benar dalam diri seseorang agar menghasilkan kemantapan amal dan
\end{abstract}


tingkah laku yang baik yang berlandaskan keimanan. Konsep Ta'dib, pertama, sebagai kompetensi moral (akhlak) yang harus dimiliki oleh pendidik maupun peserta didik, kedua, pembentukan kepribadian agar karakteristik psikologis seseorang yang berkaitan dengan kecendrungan untuk berhubungan sosial dengan orang lain, khususnya yang berkaitan dengan; keramahan, pengendalian diri, implementasi bisa dikatakan berhasil karena pendidikan adab yang diterapkan dalam kehidupan peserta didik, namun harus diakui juga dimasa pademik pendidikan Ta'dib mengalami sedikit kendala, seperti tingkat pendidikan, Lingkungan, Budaya, Tingkat sosial ekonomi dan pembelajaran Daring.

Kata Kunci: Ta'dib; Pendidikan Karakter; Covid-19

\section{A. Pendahuluan}

Konsep kunci dalam pendidikan menurut al-Attas adalah adab. Pendidikan lebih tepat menggunakan kata Ta'dib yaitu penyemaian dan penanaman adab dalam diri seseorang. Al-Attas lebih cenderung menggunakan kata $T a^{\prime} d i b$ dalam menyebut istilah pendidikan daripada tarbiyah dan ta'lim (Alwi, 2017). Al-Qur'an menegaskanbahwa contoh ideal bagi orang yang beradab adalah Nabi Muhammad saw (Dasar, 2016).

Al-Attas mengajukan agar definisi pendidikan Islam diganti menjadi penanaman adab dan istilah pendidikan dalam Islam menjadi Ta'dib (Suyuthi, 2011). Alasan yang dikemukakan ketika mengajukan definisi dan istilah baru untuk pendidikan Islam tersebut sangat konsisten dengan perhatiannya terhadap akurasi dan autentisitas dalam memahami ide-ide dan konsep-konsep Islam. Disebabkan oleh perubahan yang sangat mendasar dalam penggunaan istilah Ta'lim, Tarbiyah dan Ta'dib yang berbeda dari yang selama ini dipakai, dapat dipahami mengapa komite menerima usulan tersebut secara kompromis yaitu dengan mengungkapkan bahwa arti pendidikan secara keseluruhan terdapat dalam istilah Tarbiyah, Ta'lim dan Ta'dib yang dipakai secara bersamaan (Antoni, 2017).

Fenomena melorotnya akhlak generasi bangsa, termasuk didalamnya para elit bangsa, sering kali memberikan kritik pedasnya terhadap institusi pendidikan (Sholeh, 2014) (Yunus \& Nurseha, 2020). Hal tersebut teramat wajar karena pendidikan sesungguhnya memiliki misi yang amat mendasar yakni membentuk manusia utuh dengan akhlak mulia sebagai salah satu indikator utama, generasi bangsa dengan karakter akhlak mulia merupakan salah satu profil yang diharapkan dari praktek pendidikan nasional (Y. Bayu \& Rahmadina, 2020). Adanya kata-kata berakhlak mulia dalam rumusan tujuan pendidikan nasional di atas mengisyaratkan bahwa bangsa Indonesia mencitacitakan agar akhlak mulia menjadi bagian dari karakter nasional. Hal tersebut diharapkan dapat terwujud melalui proses pendidikan nasional yang dilakukan secar berjenjang dan berkelanjutan. 
Terlebih bangsa Indonesia dengan mayoritas muslim menjadi daya dukung tersendiri bagi terwujudnya masyarakat dengan akhlak yang dilandasi oleh nilai-nilai Islam. Hal tersebut dikarenakan akhlak menjadi bagian integral dari struktur ajaran Islam (akidah, syariah dan akhlak) (Raharjo, 2010) (Ruyadi, 2010) (Zuhdi, 2012).

Dalam mendidik dan mengasuh anak, terdapat berbagai macam cara mendidik dan bentuk pola asuh yang dapat dipilih dan digunakan oleh orang tua. Sudah menjadi kodrat manusia pada kedudukan sebagai hamba-Nya diwajibkan berusaha dengan segenap daya tanpa berputus asa. Termasuk dalam hal mendidik anak agar menjadi anak yang saleh. Sebagaimana firman Allah SWT dalam Q.S. Al-Tahrim/66:6.

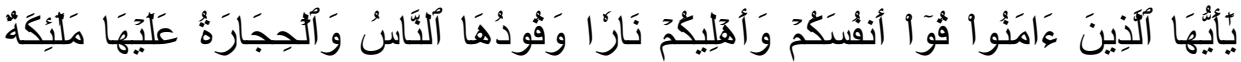

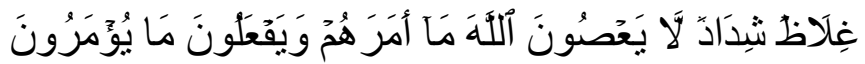

Hai orang-orang yang beriman, peliharalah dirimu dan keluargamu dari api neraka yang bahan bakarnya adalah manusia dan batu; penjaganya malaikatmalaikat yang kasar, keras, dan tidak mendurhakai Allah terhadap apa yang diperintahkan-Nya kepada mereka dan selalu mengerjakan apa yang diperintahkan.

Dalam ayat ini, Allah memerintahkan orang-orang yang beriman agar menjaga dirinya dari api neraka yang bahan bakarnya terdiri dari manusia dan batu, dengan taat dan patuh melaksanakan perintah Allah. Mereka juga diperintahkan untuk mengajarkan kepada keluarganya agar taat dan patuh kepada perintah Allah untuk menyalamatkan mereka dari api neraka. Keluarga merupakan amanat yang harus dipelihara kesejahteraannya baik jasmani maupun rohani.

Tuntutan untuk mencapai kemuliaan sebagai makhluk terbaik, maka manusia sudah seharusnya dibina dan dididik. Karena setiap manusia yang lahir di muka bumi ini masih dalam keadaan fitrah. Sebagaimana diterangkan dalam sebuah hadits Nabi sebagai berikut:

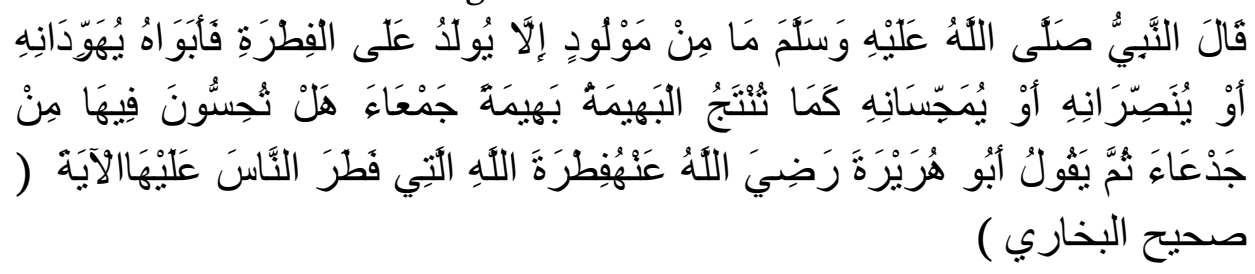

Nabi shallallahu 'alaihi wa sallam bersabda: "Tidak ada seorang anakpun yang terlahir kecuali dia dilahirkan dalam keadaan fithrah. Maka kemudian kedua orang tuanyalah yang akan menjadikan anak itu menjadi Yahudi, Nashrani atau Majusi sebagaimana binatang ternak yang melahirkan binatang ternak dengan sempurna. Apakah kalian melihat ada cacat padanya?". Kemudian Abu Hurairah radliyallahu 'anhu berkata (mengutip firman Allah, yang artinya): Sebagai fitrah Allah yang telah menciptakan manusia menurut fitrah itu (HR. al-Bukhari) 
Ayat dan hadis tersebut menjelaskan bahwa sebagai orang tua harus mengajarkan dan menanamkan nilai-nilai kebaikan kepada anak karena inilah amalan paling nyata dan paling tepat serta efektif yang harus dilakukan oleh orang tua untuk kebahagiaan mereka di dunia dan akhirat. Pembinaan anak secara tepat dan efektif merupakan salah satu tantangan paling besar bagi orang tua masa kini. Orang tua merupakan orang yang pertama kali berinteraksi dengan anak, sehingga orang tualah yang dianggap paling mampu memberikan pendidikan pada anak-anaknya, sehingga peran orang tua sangatlah penting dalam membentuk pribadi anak, menjadi pribadi yang baik dan mandiri.

Beberapa permasalahan yang sering dialami oleh seorang guru dalam menanamkan nilai agama di sekolah di MIS Al-Falah Desa Patoloan Kecamatan Bone-Bone, seperti (1) Tidak disiplin dalam mengumpulkan tugas bahkan masih banyak peserta didik pada saat belajar luring/daring tidak memperhatikan pelajaran yang diberikan guru. (2) Berkomunikasi dengan guru kurang sopan, misalnya lewat aplikasi WA. (3) Ketidakjujuran peserta didik seperti menyontek pekerjaan teman (tugas diberikan guru melalui pembelajaran luring/daring), tidak berani mengakui kesalahan yang diperbuatnya.

Muhammad Naquib Al-Attas merupakan ilmuwan berkewarganegaraan Malaysia, nama lengkap Syed Muhammad Naquib Ibn Ali Ibn Muhsin alAttas, lahir pada tanggal 5 September 1931 di Bogor, Jawa Barat Indonesia. Silsilah keluarga dapat dilacak hingga ribuan tahun ke belakang melalui silsilah "Sayyid" dalam keluarga Ba'lawi di Hadromaut dengan silsilah yang sampai kepada Imam Husein, cucu nabi Muhammad Salah satu konsep pendidikan yang fundamental bagi Al-Attas adalah Ta'dib (Alwi, 2017) (Suyuthi, 2011). Permasalahan dalam dunia pendidikan Islam ini adalah punahnya nilai-nilai adab, dengan ada adab maka akan mencakup seluruh nilai-nilai pendidikan. Al-Attas berpendapat bahwa dengan konsep adab yang diterapkan dalam dunia pendidikan Islam dari segala aspeknya maka seluruh permasalahan perkembangan Muslim dapat dibenahi, inilah yang menjadi suatu alasan istilah pendidikan dalam Islam dipakai dengan al-Ta'dib.

Kecenderungan Al-Attas pendidikan Islam itu dengan menggunakan Ta'dib dalam arti "adab" daripada "tarbiyyah dan ta'lim disebabkan bahwa akhlak itu sangat berpengaruh terhadap tingkat kualitas pengetahuan yang dimiliki. Orang yang memiliki pengetahuan itu wajib menyalurkannya kepada orang yang membutuhkan, penyaluran itu tidak akan baik jika tidak memiliki adab yang baik dalam menerimanya. Karena adab itu lebih tinggi dan mulia derajatnya daripada ilmu. 
Al-Ta'dib adalah pendidikan tepat atau cocok dalam menyebutkan konteks pendidikan dalam pandangan Islam, karena di dalamnya terkandung segala aspek dalam dunia Islam. Jika memakai term al-Ta'dib maka dunia pembelajaran Islam orientasinya kepada membimbing seseorang kepada jalan yang tepat untuk sampai kepada pemilik ilmu dan sebagai penyerahan diri kepada zat yang wajib wujud.

Pendidikan dalam konteks Islam pada umumnya mengacu kepada term Tarbiyah, Ta'dib, dan Ta'lim. Dari ketiga istilah tersebut term yang populer digunakan dalam praktek pendidikan Islam adalah term Tarbiyah. Sedangkan term Ta'dib dan Ta'lim jarang sekali digunakan. Kedua istilah tersebut telah digunakan sejak awal pertumbuhan pendidikan Islam.

Konsep Ta'dib dalam pendidikan menjadi sangat penting diketengahkan, mengingat semakin terlihatnya gejala keruntuhan akhlak di kalangan umat Islam bukan dikarenakan mereka tidak mempunyai ilmu pengetahuan, tetapi karena mereka telah kehilangan adab. Bertambahnya ilmu pengetahuan seakan-akan tidak berbanding lurus dengan peningkatan akhlak yang mulia atau keimanan.

Mengadopsi seluruh istilah atau menggabungkannya sebagai upaya untuk mengakomodasi saja tidaklah cukup, mengingat strukturnya dan penekanannya akan berbeda. Apabila $T a^{\prime} d i b$ adalah istilah yang paling mewakili pendidikan dalam islam, maka adab akan menjadi stressing dalam pendidikan secara keseluruhan, tidak hanya pada pendidikan agama saja. Demikian tarbiyyah dan ta'lim merupakan istilah yang memiliki kaitan erat langsung dengan pendidikan itu sendiri. Proses pengembangan diri dan pengajaran adalah bagian penting dalam pendidikan untuk mencapai tujuan manusia sebagai hamba Allah.

\section{B. Metode Penelitian}

Metode yang digunakan penelitian kualitatif dengan pendekatan pedagogis (Berg, 2004). Sedangkan data sekunder diambil dari dokumen yang ada kaitannya dengan penelitian. Instrumen yang digunakan dalam mengumpulkan data adalah peneliti sendiri yang berfungsi menetapkan dan memilih informan sebagai sumber data, analisis data, menafsirkan data, serta instrumen dalam mengumpulkan data adalah observasi, wawancara, dan dokumentasi.

\section{Hasil Penelitian dan Pembahasan}

\section{Integrasi $\mathbf{T a}^{\prime} \mathrm{dib}$ dalam Pembinaan Karakter}

Al-Attas, salah seorang sarjana Muslim yang mendefinisikan arti pendidikan secara sistematis, menegaskan dan menjelaskan bahwa tujuan pendidikan dalam Islam adalah untuk menciptakan manusia yang baik (good man), bukan seperti dalam peradaban Barat menghasilkan warga 
negara yang baik (good citizen). Al-Attas berpendapat bahwa warga negara yang baik dalam sebuah negara sekuler tidak sama dengan manusia yang baik; sebaliknya, manusia yang baik sudah pasti seorang warga negara yang baik (Mu'ammar, 2013). Batasan "baik" dalam frasa manusia yang baik (good man) maksudnya adalah adab dalam pengertian yang komprehensif, yang meliputi kehidupan spiritual dan material seseorang, yang berusaha menanamkan kualitas kebaikan yang diterimanya.

Menurut al-Attas orang baik adalah orang yang menyadari sepenuhnya tanggung jawab dirinya kepada Tuhan Yang Hak; yang memahami dan menunaikan keadilan terhadap dirinya sendiri dan orang lain dalam masyarakat terus berupaya meningkatkan setiap aspek dalam dirinya menuju kesempurnaan sebagai manusia yang beradab.

Apabila spiritualitas anak sudah tertata, maka akan lebih mudah untuk

menata aspek-aspek kepribadian lainnya. Maksudnya, kalau kecerdasan spiritualanak berhasil ditingkatkan, secara otomatis akan meningkatkan kecerdasan-kecerdasan lainnya seperti kecerdasan emosional (emotional quotient), kecerdasan memecahkan masalah (adversity quotient) dan kecerdasan intelektual (intellectual quotient). Inilah sebenarnya kunci mengapa aktifitas pendidikanyang berbasis agama lebih banyak berhasil dalam membentuk kepribadian anak (Manullang, 2013) (Rosmiati, 2014).

Konteks tujuan pendidikan, hal ini akan mampu membentuk anak didik yang memiliki kekokohan akidah (quwwatul aqidah), kedalaman ilmu (quwwatul ilmi), ketulusan dalam pengabdian (quwwatul ibadah) dan keluhuran pribadi (akhlakul karimah) (Pulungan, 2011) (Ruyadi, 2010). Pendidikan Islam bertujuan untuk memberikan keperibadian sebagai khalifah Allah swt. Tujuan utama khalifah Allah adalah beriman kepada Allah dan tunduk serta patuh secara total kepadanya yang didasarkan pada sifat dasar manusia, yaitu tubuh, ruh, dan akal yang masing-masing harus dijaga.

Pendidikan karakter seharusnya berangkat dari konsep dasar manusia: fitrah. Setiap anak dilahirkan menurut fitrahnya, yaitu memiliki akal, nafsu (jasad), hati dan ruh. Konsep inilah yang sekarang lantas dikembangkan menjadi konsep multiple intelligence. Dalam Islam terdapat beberapa istilah yang sangat tepat digunakan sebagai pendekatan pembelajaran. Konsep-konsep itu antara lain: tilâwah, ta'lìm', tarbiyah, ta'dîb, tazkiyah dan tadlrîb. Tilâwah menyangkut kemampuan membaca; ta'lim terkait dengan pengembangan kecerdasan intelektual (intellectual quotient); tarbiyah menyangkut kepedulian dan kasih sayang secara naluriah yang didalamnya ada asah, asih dan asuh; ta'dîb terkait dengan pengembangan kecerdasan emosional (emotional quotient); tazdkiyah terkait 
dengan pengembangan kecerdasan spiritual (spiritual quotient); dan tadlrib terkait dengan kecerdasan fisik atau keterampilan (physical quotient atau adversity quotient).

Metode pembelajaran yang menyeluruh dan terintegrasi. Pendidik yang hakiki adalah Allah, guru adalah penyalur hikmah dan berkah dari Allah kepadaanak didik. Tujuannya adalah agar anak didik mengenal dan bertaqwa kepada Allah, dan mengenal fitrahnya sendiri. Pendidikan adalah bantuan untuk menyadarkan, membangkitkan, menumbuhkan, memampukan dan memberdayakan anak didik akan potensi fitrahnya (Hafid, 2016) (Lubis, 2020). Pendidikan yang menghargai keunikan individu, serta menekankan kesadaran karakter dirinya sebagai manusia. Hal ini sesuai yang ditegaskan Al-Attas dalam Filsafat pendidikannya sangat jelas menekankan kepada pengembangan individu. Individu yang kebersamaan dengan itu sebagai bagian dari sosial dalam upaya pengembangan dirinya. Lebih lanjut Al-Attas mengatakan, "ketika kami menyatakan bahwa tujuan dari pada ilmu pengetahuan adalah melahirkan manusia yang baik, bukanlah berarti bahwa kami tidak bermaksud untuk melahirkan masyarakat yang baik, sebab masyarakat adalah terdiri daripada individu, maka melahirkan seseorang akan melahirkan masyarakat yang baik. pendidikan adalah pembuat struktur masyarakat (Suyuthi, 2011)".

Al-Attas menekankan pendidikan dalam rangka manusia beradab adalah individu yang sadar sepenuhnya akan individualitas dan sadar akan hubunganyang tepat dengan diri, Tuhan dengan masyarakat dan dengan alam yang nampak maupun yang ghaib. Al-Attas selanjutnya memberikan ilustrasi betapa adab hadir dalam berbagai tingkat pengalaman manusia (Suyuthi, 2011). Pertama, terhadap diri sendiri bermula ketika seseorang itu mengakui bahwa dirinya terdiri dari dua unsur, yaitu akal dan sifat-sifat kebinatangannya, maka ia sudah meletakkan keduanya pada tempat yang semestinya dan oleh sebab itu dia telah meletakkan dirinya pada tempat yang benar. Kedua, adab dalam kontek ilmu, berarti ketertiban budi yang mengenal dan mengakui hirarki ilmu berdasarkan kriteria tentang tingkat keluhurusan dan kemulian. Mengenal fardhu 'ayn (kewajiban bagi dirinya) dan fardhu kifayah (kewajian bagi masyarakat) yang berarti bahwasegala sesuatu yang berisi petunjuk kehidupan jauh lebih mulia dari segala sesuatu yang yang dipakai dalam kehidupan. Sebagai konsekuensinya adabterhadap ilmu pengetahuan akan menghasilkan cara-cara yang tepat dan benardalam belajar dan penerapan berbagai bidang sains bagi kehidupan.

Konsep Ta'dib digunakan untuk membangkitkan kalbu (EQ) dalam diri peserta didik. Ta'dib lebih berfungsi pada pendidikan nilai 
danpengembangan iman dan taqwa. Dalam pendidikan kalbu ini, sasarannya adalahterbentuknya anak didik yang memiliki komitmen moral dan etika. Sedangkan out putnya adalah anak yang memiliki karakter, integritas dan menjadi mujaddid. Mujaddid adalah orang yang memiliki komitmen moral dan etis dan rasaterpanggil untuk memperbaiki kondisi masyarakatnya.

Konsep Ta'dib dalam kontek pendidikan yang baik tidak bisa dilepaskankemanfaatannya dan sangat berhubungan dengan kata-kata kunci dalam pandangan hidup Islam, seperti kebijaksanaan (hikmah) dan keadilan (adl), realitas dan kebenaran (haqq). Ta'dib sebagai konsep Pendidikan Islam,pendidikan karakter manusia-manusianya, agar lebih beradab dan manusiawi. Gagasan-gagasan Al-Attas tentang Ta'dib tiada lain konseptualisasi pendidikanv slam. Mempraktikkan gagasan Islamisasi Ilmu pengetahuan dalam pendidikan. Manusia-manusia baik yang layak menghuni bumi. Sebuah upaya mengungkapmakna $T a$ 'dib bagi pendidikan agar menjadi arah dan bahan dalam rangkamembangun pendidikan karakter manusia Indonesia.

Gagasan Ta'dib adalah ingin mencetak ilmuan yang beradab. Manusia beradab sebagaimana diterangkan di atas adalah manusia yang menerapkan adab dalam setiap aspek (Sista, 2018) (Susanti, 2013) (Jessika et al., 2020). Adab terhadap Tuhan, diri sendiri, lingkungan sosial, hubungan antar sesama manusia, bahasa, alam, dan ilmu. Adab kepada ilmu, akan berpengaruh besar terhadap adab kepada objek-objek yang lainnya. Menurut al-Attas intelektual yang beradab kepada ilmu akan mengenal dan mengakui bahwa seorang berilmu kedudukannya lebih luhur dan mulia dan ilmu-ilmu fardlu 'ain dan syari'ah harus dikuasai terlebih dahulu sebelum ilmu-ilmu yang lainnya. Adab seperti ini akan menghasilkan metode yang tepat dalam memperoleh ilmu.

Berdasarkan pemaparan adab dan manusia yang baik, peneliti bisa memberi kesimpulan bahwa pengertian manusia yang beradab dan yang baik, yakni individu yang sadar sepenuhnya akan individualitasnya dan hubungannya yang tepat dengan diri, Tuhan, masyarakat, dan alam sekitarnya. Sejalan dengan di atas, dalam pandangan Islam, manusia yang beradab dan yangbaikharus menjadi hamba yang baik bagi Tuhannya, ayah yang baik bagi anak-anaknya, suami yang baik bagi istrinya, anak yang baik bagi orangtuanya, tetangga yang baik, peserta didik yang baik, guru yang baik, dan warga yang baik bagi bangsa dan negaranya.

Pada masa pandemi covid-19 di Indonesia, pemerintah membuat beberapa kebijakan untuk menghentikan penyebaran wabah virus ini dan melakukan pencegahan, seperti melakukan lockdown atau Pembatasan Sosial Berskala Besar di daerah yang sudah termasuk ke dalam zona merah 
penyebaran virus, social distancing serta physical distancing untuk menghindari penyebaran virus secara kontak fisik (Islamy, 2020) (Kaddi, Lestari, \& Adrian, 2020) (Putro \& Khamim, 2020). Selain itu penutupan sekolah menjadi langkah pemerintah untuk memutus rantai penyebaran Covid-19 yang berdampak besar bagi sektor pendidikan yang mengakibatkan diberlakukannya pembelajaran daring dimana peserta didik tidak diperkenankan untuk pergi ke sekolah dan belajar di rumah masing-masing.

Padahal sekolah secara keseluruhan adalah media interaksi antar peserta didik dan guru untuk meningkatkan kemampuan intelegensi, skill dan rasa kasih sayang di antara mereka. Tetapi sekarang kegiatan yang bernama sekolah berhenti dengan tiba-tiba karena pandemi Covid-19 (Bayu et al., 2020) (Yusuf et al., 2020). Dengan adanya penutupan sekolah anak peserta didik akhirnya tidak dapat berinteraksi dengan temantemannya, juga guru-gurunya. Sebenarnya kemampuan kognitif dan keterampilan sosial dapat dibangun oleh interaksi peserta didik dengan keluarganya.

Upaya yang dilakukan oleh guru yaitu berusaha untuk menanamkan kesadaran beribadah pada peserta didik di tengah pandemi walaupun melalui pembelajaran daring, dengan memberikan peserta didik tugas yang berkaitan dengan ibadah dan menerapkan dalam kehidupan sehari-hari, berusaha meningkatkan kualitas ibadah dengan bekerja sama dengan keluarga peserta didik karena peserta didik di saat pandemi Covid-19 ini peserta didik lebih banyak memiliki waktu luang di rumah sehingga bisa diisi dengan kegiatan yang bisa meningkatkan kualitas ibadahnya dengan bimbingan keluarganya.

Terkait dengan pembelajaran daring memberikan dampak terhadap kualitas pembelajaran peserta didik. orangtua dengan persepsi baik ataupun menganggap bahwa pembelajaran daring efektif tentu berdampak pada baiknya kualitas pembelajaran Begitu juga dengan sebaliknya persepsi orangtua yang menganggap pembelajaran daring yang tidak efektif tentu berdampak pada buruknya kualitas pembelajaran. Orangtua yang menganggap bahwa pembelajaran daring efektif dipergunakan selama masa pandemi Covid-19 tentu akan serta-merta mendukung pembelajaran yang diterapkan oleh lembaga pendidikan.

Menyikapi hal ini maka pihak MIS Al-Falah Desa Patoloan Kec. Bone-Bone memberikan alternatif kepada orangtua peserta didik terkait dengan proses pembelajaran. Pihak sekolah mengundang para orangtua peserta didik sebelum pembelajaran di awal semester dimulai untuk mendiskusikan sistem pembelajaran yang akan dilaksanakan selama satu semester ke depan, dalam hal ini pihak sekolah meminta orangtua untuk 
membuat surat pernyataan dan menandatanganinya terkait dengan kesediaan orangtua dalam pembelajaran daring.

Terkait dengan sistem pembelajaran daring tidak jarang juga orangtua kerap mengajukan kritik ataupun protes terhadap sistem pembelajaran. Kondisi ini tentu mengganggu jalannya proses pembelajaran sebab pihak sekolah harus menyediakan dua model pembelajaran, orangtua yang setuju dengan pembelajaran tatap muka dengan protokoler kesehatan maka melakukan pembelajaran secara protokol kesehatan akan tetapi bagi orangtua yang tidak setuju maka harus melakukan pembelajaran secara daring tentu kondisi ini berdampak pada pekerjaan guru yang semakin berat (Putro \& Khamim, 2020) (Sumarni, 2020). Bahkan hasil pembelajaran akan berbeda antara peserta didik yang melakukan pembelajaran secara tatap muka dengan peserta didik yang melakukan pembelajaran secara daring.

Penerapan pendidikan dimasa Covid-19 ini sangatlah kurang kondusif, dan hasilnya tidak bisa semaksimal apabila langsung tatap muka dengan guru, serta nilai pentingnya tidak normalnya adab antara guru dan peserta didik, kalau pembelajaran tatap muka langsung peserta didik itu berbusana rapi dan duduk sopan menghargai guru, tetapi dengan adanya belajar daring adabnya pun tidak terpuji, karena baik buruknya adab sangat berpengaruh dengan keberhasilan memperoleh pemahaman dan keberkahan ilmunya.

Konsep pendidikan karakter dalam pembelajaran pai sudah diterapkan di kelas, namun tentang konsep Ta'dib Muhammad Naquib alAttas baru mengetahuinya, metode yang digunakan dalam pembelajaran PAI terkait dengan penanaman nilai akhlak adalah bimbingan, motivasi dan keteladanan (Suyuthi, 2011). Konsep pendidikan Ta'dib Al-Attas bisa diimplementasikan dalam pengembangan karakter peserta didik, cara mengintegrasikan nilai-nilai akhlak di luar kelas yaitu dengan cara peserta didik di biasakan untuk menerapkan apa yang sudah dipelajari di kelas seperti mengucapkan salam dengan teman dan orang yang lebih tua, menjenguk teman apabila sakit. Proses pembelajaran pai adalah dengan ceramah, diskusi dan kuis. pembiasaan yang dilakukan dalam pembinaan akhlak adalah eskul, pramuka, shalat dhuha, shalat zuhur (sebelum masa pandemi), berjabat tangan dengan guru, mengucapkan salam, membaca do'a-do'a, menghafal surat-surat pendek. Hambatan dalam implementasi konsep $\mathrm{Ta}^{\prime} \mathrm{dib}$ adalah kurangnya respon orangtua karena sebagian besar orangtua adalah peagang yang seharian berjualan di pasar).

Penerapan Pendidikan Agama Islam di masa pandemi Covid-19 yang paling penting adalah pembelajaran harus terjadi meski di rumah, tanpa guru, dan harus memiki target bahwa kurikulum harus tercapai. Bukan 
memindahkan sekolah di rumah, dengan memilih materi-materi esensial yang tidak membuat peserta didik bosan. Yang kedua tenaga pengajar atau guru harus memberikan pendidikan kepada anak-anak tentang kecakapan hidup, tentang perilaku dan akhlak di rumah yakni pendidikan yang bersifat kontekstual sesuai kondisi rumah masing-masing, terutama tentang agama, dan juga pengertian tentang Covid-19.

Penerapan pendidikan Agama Islam melalui daring ditengah wabah Covid-19, ini sangat merugikan guru dan peserta didik, sebab guru kurang efisien dalam menyampaikan materi pembelajaran, dan peserta didik juga kurang menangkap materi pemebelajaran sebab anak tidak dapat mengajukan berbagai macam pertanyaan seperti biasa di kelas karena waktu dan tempat tidak memungkinkan. Juga belum tentu semua peserta didik dapat online ketika jam pelajaran karena berbagai sebab, misalnya karena tidak ada sinyal, atau mungkin tidak memiliki kuota dll.

Saat ini yang dilakukan itu pembelajaran secara daring, pembelajaran ini dilakukan di rumah agar tidak terjadinya penularan Covid yang sudah sampai ribuan korban. Dalam pembelajaran daring ini dari segi positifnya anak dan orangtua lebih banyak berinteraksi satu sama lain dan orangtua lebih mengetahui gaya belajar anaknya masing-masing. Kemendikbud membuat peraturan bahwa pendidikan di Indonesia tetap berjalan seperti biasanya, tetapi ada hal yang berbeda didalamnya, Yaitu dengan sistem pembelajaran dari rumah masing-masing. Dalam hal ini khususnya para orangtua peserta didik harus mampu menjalin komunikasi dan interaksi kepada masing-masing anaknya dan mampu untuk membimbing anakanaknya agar tetap belajar secara maksimal dan optimal walaupun pembelajaran dilakukan di dalam rumah.

Peran aktif menurut orangtua juga sangat membantu proses emosional anak, yang dapat ditinjau menurut bentuk dukungan yang berkaitan dengan pembentukan dan perkembangan emosional anak, yaitu: melepaskan daya kreasi dan imajinasi anak yang berdampak positif dan tentunya anak selalu terarah. Sebaliknya bila orangtua kurang memberikan perhatian terhadap emosional anak, memberikan kesempatan kepada anak, maka akan membawa dampak negatif terhadap perkembangan emosional dalam anak. Sikap saling dan perhatian adalah kunci utama dalam menciptakan suatu hubungan yang serasi antara anak dan orangtua. Pola interaksi yang terjalin secara baik maka menciptakan suasana yang indah dan berdampak positif untuk perkembangan anak tersebut. Karena membangun interaksi yang baik dan mendukung serta memotivasi anak supaya tetap semangat dalam pembelajaran walaupun dilakukan di rumah akan membangkitkan motivasi anak dan emosional anak agar lebih 
semangat dalam belajar dan tidak mudah mengeluh dalam situasi yang terjadi saat ini.

Dengan diberlakukannya kebijakan pembelajaran di rumah, hubungan seorang anak dengan kedua orangtua yang sebelumnya bisa dikatakan belum optimal atau mungkin sekedarnya saja. Namun saat ini orangtua mampu untuk mengawasi dan berperan penting demi kemajuan dan kelancaran proses pembelajaran anaknya. Orangtua harus mampu menjadi seorang yang mampu memotivasi dan memberikan semangat kepada anaknya agar tetap selalu semangat dalam melakukan pembelajaran dan tidak mudah mengeluh atas apa yang terjadi saat ini. Ibu dan Bapak dari seorang anak harus mampu membuat anaknya menjadi orang yang baik, mendidiknya supaya tidak menjadi seorang pemalas dan tidak berkompeten.

Didikan orangtua sangat besar pengaruhnya terhadap perkembangan sikap dan psikologis seorang anak. Maka sebaiknya sebagai orangtua selalu memberikan arahan-arahan terbaik dan motivasi kepada anaknya agar anaknya tidak menjadi seorang yang tidak mau perduli dengan nasehat ataupun ucapan orang lain. Kebijakan pembelajaran di rumah dapat dikatakan banyak hikmahnya juga, dikarenakan pola hubungan antara anak dan orangtua bisa lebih terjalin dan orangtua bisa lebih mengawasi anak-anaknya dalam proses pembelajaran yang dilakukan secara daring di rumah. Apalagi anak tersebut masih dalam masa perkembangan. Maka orangtua harus menaruh perhatian khusus dan mengamati anak tersebut, supaya tidak salah arah dan selalu menuju jalan kebaikan lewat arahan-arahan ataupun nasehat yang diberikan sang orangtua kepada anaknya.

Konsep Ta'dib berimplikasi pada kepribadian dan adab seorang pendidik yang mxengharuskan pendidik memiliki adab yang baik sehingga menjadi panutan bagi peserta didiknya. Selain itu, dalam konsep ini juga terdapat kecenderungan untuk selalu memperhatikan kepribadian atau adab peserta didik dalam mencari ilmu pengetahuan sehingga dapat mengamalkan pengetahuannya dengan benar dan tepat. Peserta didik harus memiliki keikhlasan niat dalam menuntut ilmu yang bertujuan untuk mencari ridha Allah dan membersihkan hati. Pada konsep ini, dalam muatan kurikulum terdapat kategorisasi ilmu pengetahuan atau hirarki ilmu pengetahuan.

\section{Relevansi $T a^{\prime} d i b$ dengan pendidik dan peserta didik}

Konsep Ta'dib yang diformulasikan al-Attas mempunyai relevansi dengan pendidikan akhlak, maka dengan sendirinya konsep Ta'dib mempunyai relevansi dengan pendidik dan peserta didik. Dalam konteks 
pendidikan akhlak, Ta'dib bisa diartikan sebagai kompetensi moral (akhlak) yang harus dimiliki oleh pendidik maupun peserta didik, disamping komptenesikompetensi yang lainnya. Sebagai contoh pendidik harus suci baik jasmani maupun rohaninya, ikhlas, pemaaf, sabar, bijaksana, adil, mencintai dan menyayangi peserta didik seperti anaknya sendiri, memberikan teladan yang baik, dan sebagainya. Begitu pula dengan peserta didik, ia harus mempunyai kriteria akhlak (moral) sebagai berikut: memurnikan niat, ikhlas, tekun dan giat dalam belajar, disiplin, sabar, rendah hati, lapang dada, hormat terhadap guru, dan sebagainya. (Lubis, 2019) (Maryani, 2020) (Irawati \& Elmubarok, 2014)

Pendidikan diberikan kepada peserta didik sebagai subjek dan objek pendidikan. Dikatakan subjek karena ia mengembangkan dan mengaktualisasi potensinya sendiri, sedangkan pendidik hanya menstimulasinya dalam pengembangan dan aktualisasi tersebut. Sedangkan peserta didik disebut objek karena menjadi sasaran transformasi ilmu pengetahuan dan nilai Islam, agar ilmu dan nilai itu tetap terjaga dari generasi ke generasi berikutnya. Melalui upaya pengajaran, pembiasaan, bimbingan, pengasuhan, pengawasan dan pengembangan potensi, maksudnya, tugas pokok pendidikan adalah memberikan pengajaran, pembiasaan, bimbingan, pengasuhan, pengawasan dan pengembangan potensi peserta didik agar terbentuk dan berkembang daya kreativitas dan produktivitasnya tanpa mengabaikan potensi dasarnya. Guna mencapai keselarasan dan kesempurnaan hidup di dunia dan akhirat, artinya, tujuan akhir pendidikan Islam adalah tercipta insan kamil (manusia sempurna), yaitu manusia yang mampu menyelaraskan dan memenuhi kebutuhan dunia dan akhirat, kebutuhan fisik, psikis, sosial dan spiritual.

Berdasarkan pada paparan yang telah terurai secara lebih mendalam tentang konsep Ta'dib yang diformulasikan oleh al-Attas tampak sangat erat kaitannya dengan tujuan pendidikan akhlak yakni tercapainya akhlak al-Karimah. Akhlak al-Karimah merupakan essensi, elan vitale dan ruh ajaran Islam itu sendiri. Tujuan ini konsiderans dengan misi profetisnya Rasulullah saw yakni disamping menyebarkan ajaran Islam juga memperbaiki dan menyempurnakan akhlak manusia. Al-Attas mendefinisikan Ta'dib sebagai "pengenalan dan pengakuan terhadap realitas bahwasannya ilmu (pengetahuan) dan segala sesuatu yang wujud yang ada terdiri dari hierarkhi yang sesuai dengan kategori-kategori dan tingkatan-tingkatan dan bahwa seseorang itu memiliki tempat masingmasing dalam hubungannya dengan realitas serta kapasitas, potensi fisik, intelektual, dan spiritualnya". 


\section{Kesimpulan}

Konsep Pendidikan Ta'dib titik tekan pada penguasaan ilmu yang benar dalam diri seseorang agar menghasilkan kemantapan amal dan tingkah laku yang baik yang berlandaskan keimanan. Implementasi konsep $T a{ }^{\prime} d i b$, yaitu pertama, sebagai kompetensi moral (akhlak) yang harus dimiliki oleh pendidik maupun peserta didik, kedua, pembentukan kepribadian agar karakteristik psikologis seseorang yang berkaitan dengan kecendrungan untuk berhubungan sosial dengan orang lain, khususnya yang berkaitan dengan; keramahan, pengendalian diri, implementasi bisa dikatakan berhasil karena pendidikan adab diterapkan dalam kehidupan.

\section{E. Ucapan Terima Kasih}

Sadar atas keterbatasan sehingga dalam penyelesaian studi peneliti banyak mendapat bantuan dari berbagai pihak. Oleh karena itu, peneliti mengucapkan banyak terima kasih khususnya kepada Kepala SD Negeri 156 Wonosari beserta dewan guru. Serta kepada Kepala Madrasah Ibtida'iyah (MIS) al-Falah beserta seluruh jajaran dan staf yang telah memberi kesempatan untuk mengadakan penelitian dan observasi lapangan secara mendalam hingga selesai.

$* * * * * * * * *$ 


\section{Daftar Pustaka}

Alwi, H. (2017). Konsep Ta'dib Menurut Syed Muhammad Naquib Al-Attas Dan Implikasinya Bagi Pendidikan Karakter. IAIN Salatiga, 1-143.

Antoni, S. (2017). Dewesternisasi Pendidikan Islam (Studi Atas Pemikiran Sayyid Muhammad Naquib Al-Attas). Jurnal Ilmiah AL-Jauhari (JIAJ), 2(1), 36-48.

Athoillah, N. I. (2020). Aktualisasi Nilai-nilai Profetik dalam Pendidikan Keluarga di Tengah Pandemi. Mawasizh Jurnal Dakwah Dan Pengembangan Sosial Kemanusiaan, 11(2), 29-48.

Bayu, M., Sampurno, T., Mada, U. G., Kusumandyoko, T., Surabaya, U. N., Islam, M. A., Surabaya, U. N., \& Branding, V. (2020). Budaya Media Sosial, Edukasi Masyarakat, dan Pandemi COVID-19. April. https://doi.org/10.15408/sjsbs.v7i5.15210

Bayu, Y., \& Rahmadina, A. (2020). Peran Orang Tua dalam Menanamkan Nilai Karakter Kearifan Lokal Pada Masyarakat Pesisir. Edukasi, 14(2), 145-150.

Berg, B. L. (2004). Methods for the Social Sciences.

Dasar, D. I. S. (2016). Pembelajaran Seni Budaya Berbasis Kearifan Lokal Dalam Upaya Membangun Pendidikan Karakter Siswa Di Sekolah Dasar. Ritme, 2(1), 16-25.

Hafid, A. (2016). Hubungan Sosial Masyarakat Multietnik Di Kabupaten Luwu Sulawesi Selatan. Al-Qalam, 22(2). https://doi.org/10.31969/alq.v22i2.353

Kaddi, S. M., Lestari, P., \& Adrian, D. (2020). Komunikasi Keluarga Dalam Pencegahan Coronavirus Disease 2019. Jurnal Ilmu Komunikasi, 18(1), 63. https://doi.org/10.31315/jik.v18i1.3701

Lubis, S. (2019). Tinjauan Normatif Kurikulum Pendidikan Agama Islam Dalam Penanaman Nilai-Nilai Anti-Korupsi. Murabbi: Jurnal Ilmiah Dalam Bidang Pendidikan, STIT Al-Hikmah Tebing Tinggi, 02(01), 31-47.

Manullang, B. (2013). Grand Desain Pendidikan Karakter Generasi Emas 2045. Jurnal Pendidikan Karakter, 1, 1-14. https://doi.org/10.21831/jpk.v0i1.1283

Maryani, K. (2020). Penilaian dan Pelaporan Perkembangan Anak Saat Pembelajaran di Rumah di Masa Pendemi Covid-19. Murhum: Jurnal Pendidikan Anak Usia Dini, 1(2), 41-52. https://doi.org/10.37985/murhum.v1i1.4

Mu'ammar, M. A. (2013). Internalisasi Konsep Ta'dîb Al-Attas dalam Pengembangan Karakter Peserta Didik. Tsaqafah, 9(2), 357. https://doi.org/10.21111/tsaqafah.v9i2.57

Pulungan, S. (2011). Membangun Moralitas Melalui Pendidikan Agama. AlHikmah: Jurnal Agama Dan Ilmu Pengetahuan, 8(1), 1412-5382,. 
Putro, K. D. (2020). Pola interaksi anak dan orangtua selama kebijakan pembelajaran di rumah. Fitrah: Jurnal of Islamic Education, 1(1), 124-140.

Rahmat, R. L. dkk. (2020). Pembelajaran Al-Qur'an Era Covid-19: Tinjauan Metode dan Tujuannya pada Masyarakat di Kutacane Aceh Tenggara. Kutta: Jurnal Ilmu Pendidikan Islam, 4(2), 1-9. https://doi.org/10.30736/ktb.v4i2.275

Retno, P. I., dan Zaim, E. (2014). Pengembangan Buku Ajar Bahasa Indonesia Tematik Berkarakter Bagi Siswa Sd Melalui Sastra Anak. Jurnal Pendidikan Karakter, 2, 81-96. https://doi.org/10.21831/jpk.v0i2.2179

Rosmiati, A. (2014). Teknik Stimulasi dalam Pendidikan Karakter Anak Usia Dini melalui Lirik Lagu Dolanan. Resital: Jurnal Seni Pertunjukan, 15(1), 7182. https://doi.org/10.24821/resital.v15i1.801

Sabar, B. R.. (2010). Pendidikan Karakter sebagai Upaya Menciptakan Akhlak Mulia. Jurnal Pendidikan Dan Kebudayaan, 16(3), 229-238.

Sholeh, A. (2014). Pemahaman Konsep Tasamuh (Toleransi) Siswa Dalam Ajaran Islam. J-PAI: Jurnal Pendidikan Agama Islam, 1(1), 101-132. https://doi.org/10.18860/jpai.v1i1.3362

Sista, T. R. (2018). Implementasi Pendidikan Agama Islam Dalam Pembinaan Moral Remaja ( Studi Kasus di Pesantren Modern Muadalah dan Pesantren Salaf / Tradisional ). At-Ta'dib, 13(2), 154-167.

Susanti, R. (2013). Penerapan Pendidikan Karakter Di Kalangan Mahasiswa. $A L$ Ta Lim, 20(3), 480. https://doi.org/10.15548/jt.v20i3.46

Suyuthi, A. (2011). TA ' DIB SEBAGAI UPAYA REKONSTRUKSI PENDIDIKAN ISLAM PERSPEKTIF SYED NAQUIB AL-ATTAS. $A L$ HIKMAH, 1(September), 156-169.

Tamara, J. Sugiatno, E. Y., Warsah, I., \& Deri, W. (2020). Strategi Pembelajaran Dosen Melalui Pemanfaatan Media Whatsapp Di Masa Pandemi COVID19. At-Ta'lim: Media Informasi Pendidikan Islam, 19(2), 351-373.

Yadi, R. (2010). Model Pendidikan Karakter Berbasis Kearifan Budaya Lokal (Penelitian terhadap Masyarakat Adat Kampung Benda Kerep Cirebon Provinsi Jawa Barat untuk Pengembangan Pendidikan Karakter di Sekolah). Proceedings of The 4th International Conference on Teacher Education; Join Conference UPI \& UPSI, November, 576-594.

Yenti, S. (2020). Pandemi Covid-19: Tantangan Ekonomi Dan Bisnis. Jurnal Ekonomi Dan Perbankan Syariah, 6(2), 46-58. 
Yunus, M., Nurseha. (2020). Culture of Siri' in Learning Akidah Akhlak in MAN Suli Luwu District Budaya Siri' dalam. JIEBAR : Journal of Islamic Education: Basic and Applied Research, 01, 107-120.

Yusuf, M., Hamdani, Siregar, A. P., \& Siregar, F. N. (2020). Implementasi Pendidikan Agama Islam di Masa Pandemi Covid-19. Maslahah Jurnal Pengabdian Masyarakat, 1(1), 38-48. https://doi.org/10.30596/maslahah.v

Zuhdi, M. H. (2012). Islam Dan Pendidikan Karakter Bangsa. EL-HIKAM: Jurnal Pendidikan Dan Kajian Keislaman, 5(1), 83-103. 
Integrasi Konsep Ta'dib Al-Attas dalam Pembinaan Karakter... 